\title{
The presence and abundance of harmful dinoflagellate algae related to water quality in Jakarta Bay, Indonesia
}

\author{
ANNISA KHAIRA NASUTION ${ }^{1}$, NOVERITA DIAN TAKARINA ${ }^{2, \boldsymbol{\nu}}$, HIKMAH THOHA ${ }^{3}$ \\ ${ }^{1}$ Marine Science Graduate Program, Faculty of Mathematics and Natural Sciences, Universitas Indonesia. Jl. Prof. Dr. Sudjono D. Pusponegoro (Lingkar \\ UI), Depok16424, West Java, Indonesia \\ ${ }^{2}$ Department of Biology, Faculty of Mathematics and Natural Sciences, Universitas Indonesia. Jl. Prof. Dr. Sudjono D. Pusponegoro (Lingkar UI), \\ Depok16424, West Java, Indonesia. Tel.:+62-21-7270163, 78849009, Fax.: +61-21-78849010, 16424 Depok, West Java, Indonesia. \\ "email: noverita.dian@sci.ui.ac.id \\ ${ }^{3}$ Research Center of Oceanography, Indonesian Institute of Science. Jl. Pasir Putih No. 1, East Ancol, North Jakarta 14330, Jakarta, Indonesia
}

Manuscript received: 19 March 2021. Revision accepted: 27 April 2021.

\begin{abstract}
Takarina ND, Nasution AK, Thoha H. 2021. The presence and abundance of harmful dinoflagellate algae related to water quality in Jakarta Bay, Indonesia. Biodiversitas 22: 2909-2917. Dinoflagellate is a single-celled organism that commonly occurs in large numbers in marine environment. When environment changes, harmful dinoflagellate algae often emerge as a response to change in water quality. Jakarta Bay, Indonesia is the meeting point of 13 rivers that carry anthropogenic effluents, not only from agriculture and human settlements, but also industrial activities with some initial evidence showed the increasing growth of harmful algae population and decreasing water quality. This study aims to assess the correlations between dinoflagellate abundance and water quality parameters (i.e., dissolved oxygen, $\mathrm{pH}$, salinity, temperature, and turbidity) in Jakarta Bay. Dinoflagellates were sampled in July 2020 at four river mouths, namely Ancol, Muara Baru, Muara Angke, and Muara Karang, each with three replications. Results showed that five dinoflagellates categorized as harmful were recorded. The following order of dinoflagellates based on abundance was Noctiluca > Ceratium > Gonyaulax > Gymnodinium > Dinophysis. Dinoflagellate abundance ranges were as low as 353,857 cells $/ \mathrm{m}^{3}$ for Dinophysis and as high as $85,279,547$ cells $/ \mathrm{m}^{3}$ for Noctiluca. In terms of location, Muara Baru had the highest dinoflagellate abundance. There were correlations between dinoflagellate abundance with water quality. The dinoflagellate abundance was positively correlated with DO (Gymnodinium 0.5152; Dinophysis 0.5262; Gonyaulax 0.3701; Noctiluca 0.0429; Ceratium 0.4168) and temperature (Gymonodium 0.3894; Ceratium 0.3627; Gonyaulax 0.3428;Dinophysis 0.2536) but negatively correlated with pH (Ceratium-0.5558; Dinophysis0.4868; Gymonodinium-0.4284; Noctiluca-0.4201; Gonyaulax-0.3881), turbidity (Dinophysis-0.2336; Gonyaulax-0.0105; Noctiluca0.1164; Ceratium-0.0896), salinity (Gymnodinium-0.2176; Dinophysis-0.0888; Ceratium-0.0434).
\end{abstract}

Keywords: Abundance, correlation, dinoflagellate, Jakarta Bay, water quality

\section{INTRODUCTION}

Dinoflagellates are single-cell microorganisms which commonly live in marine ecosystem (Guiry 2012, Le Bescot et al. 2016). In this ecosystem, dinoflagellates are autotrophic organisms that play an important role as marine primary producers and grazers (Horiguchi 2015). In marine ecosystem, dinoflagellates can move around the ocean due to currents, storms, dredging of the ocean bottom and when cysts act as ballast on ships (Smayda 2007). The presence and abundance of dinoflagellates are affected by environmental factors such as temperature, light, or oxygen level changes or even resuspension of dinoflagellate's cysts by storms (Prabowo and Agusti 2019). In general, dinoflagellates will thrive when nutrient level increases and cell division is so rapid, resulting in extremely high cell counts under conditions of extremely high nutrient levels (Davidson et al. 2014). This condition is known as algal bloom or red tides.

Among dinoflagellates, several species are considered harmful since they can release toxins such as saxitoxin, gonyautoxin, brevetoxin, yessotoxin, ciguatoxin, maitotoxin, palytoxin and azaspiracid (Lassus et al. 2016). Those toxins are released by dinoflagellate genera included Alexandrium, Gymnodinium, Pyrodinium, Kerenia, Chatonella, Fibrocapsa, Heterosigma, Protoceratium, Lingulodinium, Gonyaulax, Gambierdiscus, Protoperidinium, and Ostreopsis (Lu and Hodgkiss 2004; Wang 2008). It is estimated that there are 60 dinoflagellate species considered harmful. These harmful species belong to the pennate diatoms which are long and thread-like. Some species such as Alexandrium catenella (Nagai et al. 2019), Gymnodinium catenatum (Clemenston et al. 2004) and Dinophysis acuta (Díaz et al. 2016) have been clearly reported.

The presence of harmful dinoflagellates causes problems in many parts of the world, for example in Africa (Probyn et al. 2000; Fawcett et al. 2006), America (CuellarMartinez et al. 2018; León-Muñoz et al. 2018), and Asia (Furuya et al. 2018). In recent decades, many coastal countries in Southeast Asia also experience an increasing trend of harmful algal bloom, resulting in mass mortalities of wild and cultured fishes and shellfishes (Soon and Sulit 2017). The impacts of harmful algae bloom in Southeast Asia regions include shellfish poisoning (ciguatera, diarrhetic, paralytic, tetrodotoxin), fish kills, and tainting of fish and shellfish (Corrales and Maclean 1995). Several marine ecosystems in Indonesia also experience harmful 
dinoflagellate bloom. According to Praseno and Sugestiningsih (2000), in Indonesia's coastal and sea waters there were about 30 genera of harmful alga blooms (HABs). The presence of harmful dinoflagellates had been reported in Jakarta Bay, Ambon Bay, Kao Bay and Lampung Bay (Wiadnyana et al. 1996; Matsuoka et al. 1999; Sidharta 2004; Aditya et al. 2013; Thoha et al. 2019). For example, Barokah et al. (2016) reported the abundance of 13 harmful dinoflagellates in Lampung Bay with Ceratium sp. was the most common genus with abundance of 1800 cells/L.

Jakarta Bay is one of marine ecosystems in Indonesia that have been frequently studied regarding the presence of harmful dinoflagellates. Harmful algal bloom events in Jakarta Bay continue to increase in recent years, causing massive fish kills and leading to economic losses in local fisheries, a decrease in water quality, and threat to people consuming fish from the bay. In this bay, harmful dinoflagellate population growth was accelerated by the high input of nutrients caused by anthropogenic factors. Thoha et al. (2007) found discoloration of a green-brown color in the water of Jakarta Bay in May and November 2004 with dinoflagellate abundance recorded as much as 2.5-4.2 x 106 cells/L, represented by eight dinoflagellate species. Recently, a study in Jakarta Bay confirmed the abundance of harmful dinoflagellate with total of eleven species (Sidabutar et al. 2016). Further, Sidabutar et al.
(2020) conducted a study about the variability of phytoplankton species that potentially caused alga bloom events in Jakarta Bay.

Despite the growing research on dinoflagellate presence in Jakarta Bay, information about environmental factors related to the distribution and abundance of dinoflagellate is still limited. Considering the rapid anthropogenic development in Jakarta Bay with potentially adverse effects on water quality, thus understanding dinoflagellate as function of water quality is urgently required. Therefore, this study aims to investigate the correlations between dinoflagellate abundance and water quality parameters (i.e., dissolved oxygen, $\mathrm{pH}$, salinity, temperature, and turbidity) in Jakarta Bay. This information is essential to anticipate the potential harmful dinoflagellate algal blooms in the future.

\section{MATERIALS AND METHODS}

\section{Study period and area}

The study was conducted in July 2020 at four river mouths located in Jakarta Bay, north of Jakarta, Indonesia (Figure 1). The study location is characterized by shallow bay with an average depth of $15 \mathrm{~m}$ and shoreline of $149 \mathrm{~km}$ long covering an area of approximately $595 \mathrm{~km}^{2}$.

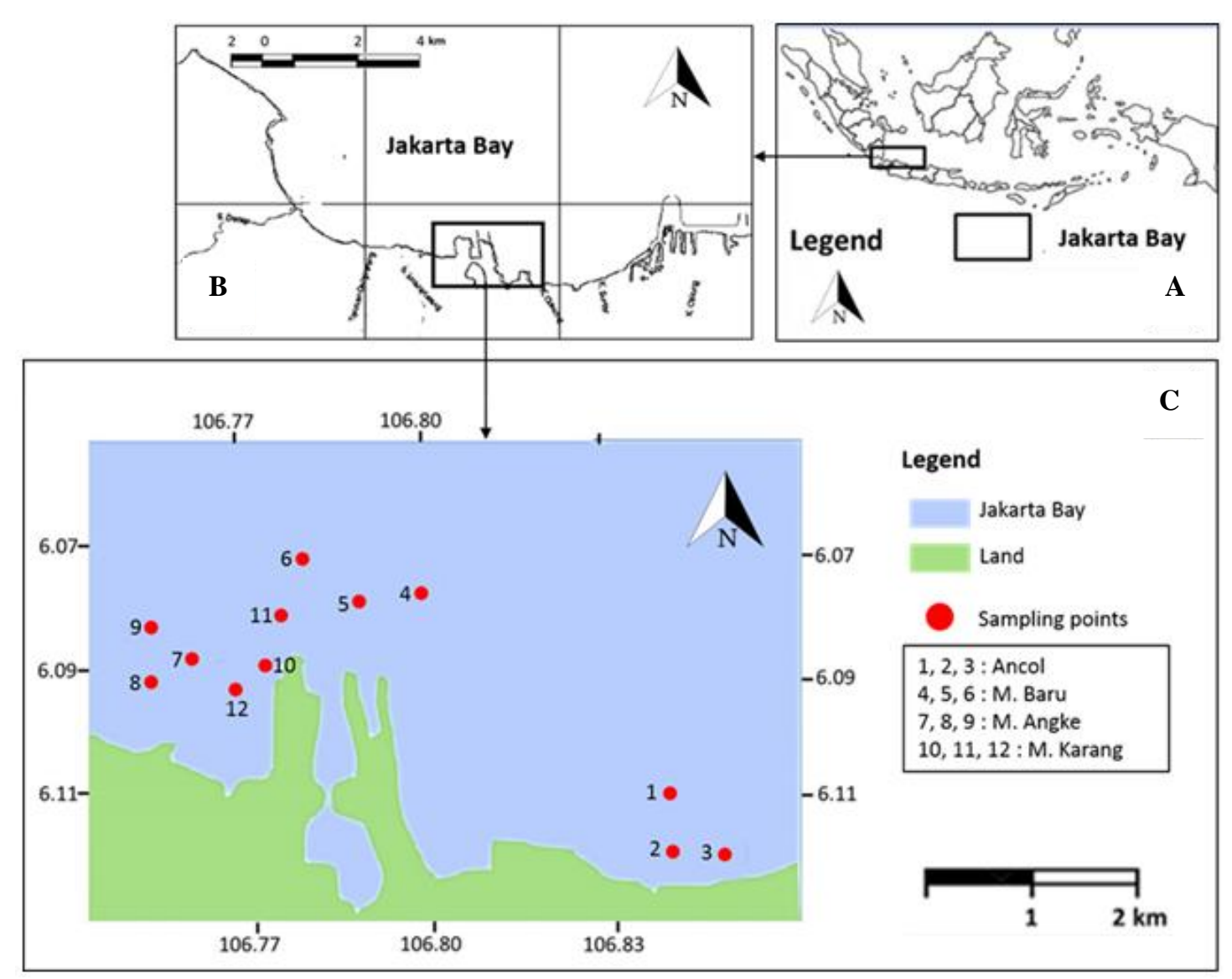

Figure 1. Map of study location showing Indonesia (A); Jakarta Bay (B); and twelve sampling points in Jakarta Bay (C) 
Twelve sampling points were established with three sampling points at each river mouth, i.e., Ancol (sampling point number 1, 2, and 3), Muara Baru (sampling point number 4, 5, and 6), Muara Angke (sampling point number 7, 8, and 9) and Muara Karang (sampling point number 10, 11, and 12). The geographical coordinates of each sampling point were recorded using Global Positioning System (GPS) handheld Etrex Garmin. Land uses surrounding Ancol was dominated by open fields and vegetations. Urban residential areas, settlements, fish auction, and ports dominated the land uses in Muara Baru and Muara Karang. While land uses surrounding Muara Angke were dominated not only by combinations of fishermen housing and vegetations, but also restaurants (Riqqi et al. 2019).

\section{Procedures}

\section{Harmful alga sampling}

The collection of harmful dinoflagellate from water in each sampling point followed the method by Sidabutar et al. (2016) using modified plankton net with mesh size of 150 microns. Collected samples were stored in bottles and preserved in $37 \%$ formaldehyde. The filtered water volume was calculated using equation of $\mathrm{v}=\pi \mathrm{r}^{2}$ multiplied by $\mathrm{d}$; with v: filtered water volume; r: radiant of net opening and d: plankton net depth lowered into the water. The identification of dinoflagellate was performed using a light microscope with 400x and 1000x magnifications, and the classification was carried out using Book of Illustrations of the Marine Plankton of Japan by Yamaji (1966) and Book of Marine Phytoplankton of the Western Pacific by Omura et al. (2012). While dinoflagellate abundance counting was performed using Sedgwick-Rafter counting chambers and the obtained abundance results expressed in cells $/ \mathrm{m}^{3}$.

\section{Water quality measurement}

Water quality variables were measured in situ at each sampling point with 3 replications (Table 1).

Table 1. Parameters of water quality at the four study sites in Jakarta Bay, Indonesia

\begin{tabular}{lcccccc}
\hline \multirow{2}{*}{$\begin{array}{l}\text { Sampling } \\
\text { point }\end{array}$} & & $\begin{array}{c}\text { DO } \\
(\mathbf{p p m})\end{array}$ & $\mathbf{p H}$ & $\begin{array}{c}\text { Temp. } \\
\mathbf{( \mathbf { }} \mathbf{C})\end{array}$ & $\begin{array}{c}\text { Salinity } \\
\mathbf{( \% )}\end{array}$ & $\begin{array}{c}\text { Turbidity } \\
(\mathbf{N T U})\end{array}$ \\
\hline Ancol & 1 & 7.23 & 5.70 & 30 & 35 & 0.75 \\
& 2 & 6.15 & 8.26 & 30 & 35 & 0.12 \\
& 3 & 5.50 & 7.74 & 30 & 35 & 0.26 \\
Average & & 6.29 & 7.23 & 30 & 35 & 0.37 \\
& & & & & & \\
Muara & 4 & 7.30 & 5.73 & 27.9 & 38 & 0.71 \\
Baru & 5 & 6.50 & 5.82 & 29.5 & 38 & 0.51 \\
& 6 & 8.40 & 5.53 & 30.1 & 38 & 0.17 \\
Average & & 7.40 & 5.69 & 29.1 & 38 & 0.46 \\
& & & & & & \\
Muara & 7 & 7.60 & 8.80 & 25 & 35 & 0.36 \\
Angke & 8 & 7.20 & 8.20 & 25 & 35 & 0.76 \\
& 9 & 7.00 & 8.50 & 25 & 36 & 1.21 \\
Average & & 7.33 & 8.50 & 25 & 35.3 & 0.77 \\
& & & & & & \\
Muara & 10 & 4.50 & 6.23 & 27.6 & 35 & 0.77 \\
Karang & 11 & 7.70 & 5.19 & 28.6 & 36 & 0.59 \\
& 12 & 7.90 & 6.03 & 30.5 & 38 & 4.20 \\
Average & & 6.70 & 5.82 & 28.9 & 36.3 & 1.85 \\
\hline
\end{tabular}

The measured variables included dissolved oxygen (DO), $\mathrm{pH}$, salinity, temperature, and turbidity. DO and temperature was measured using multi-parameter (Lutron DO 5510), pH with pH meter (Lutron PH 208), salinity was measured with refractometer (Atago), and turbidity with turbidity meter (Ezdo TUB-430).

\section{Data analysis}

The abundance of harmful dinoflagellate and water quality data were presented as relative abundance (\%). Pearson's R correlation analysis (Gharib et al. 2011) was used to test correlation significance between harmful dinoflagellate abundance and water quality variables. Principal Component Analysis (PCA) was used to group the sampling points according to their dinoflagellate abundance and water quality assemblages.

\section{RESULTS AND DISCUSSION}

\section{Water quality}

The result of water quality measurement in Jakarta Bay is presented in Table 1. The highest $\mathrm{pH}(8.5)$ was recorded in Muara Angke, with Muara Baru and Muara Karang were more acidic (5.69-5.82) (Table 1). There are settlements and ports in Muara Baru, while in Muara Karang there is an Electric Steam Power Plant (PLTU) (Annisa et al. 2019) which causes heat (high temperature) in the surrounding environment. Temperature plays a significant role in $\mathrm{pH}$ measurement (Hagens and Middelburg 2016). As the temperature rises, the molecule vibration increases, resulting in the ability of water to ionize and form more hydrogen ions. As a result, the $\mathrm{pH}$ will drop. Some of these low $\mathrm{pH}$ values were not considered the range of values that were still good for phytoplankton growth. According to Hinga (2002), $\mathrm{pH}$ of water in coastal environment is within the range of 7.5-8.5, while in the laboratory, the optimal $\mathrm{pH}$ for phytoplankton growth is between 6.3 and 10 .

The water temperature of Jakarta Bay ranged from 25 to $30.56^{\circ} \mathrm{C}$ (Table 1). These temperatures are still within the range of values that support the growth of phytoplankton. Several phytoplankton genera including marine dinoflagellates can grow well in temperatures up to $35^{\circ} \mathrm{C}$ (Boyd et al. 2013). The salinity in Jakarta Bay ranged from 35 to 38 ppt with Muara Baru was more saline than other sampling points (Table 1). These values are still needed for phytoplankton. Raymont (1980) explained that salinity range of 10-40 ppt is optimum for the growth of phytoplankton. Salinity is one of the environmental factors that can change the community structure of phytoplankton (Sew and Todd 2020) and affect the production of phytoplankton (Barron et al. 2002).

Muara Karang, the location where PLTU existed, had the highest average turbidity with 1.85 NTU (Table 1). Turbid waters become warmer as suspended particles absorb heat from sunlight, causing oxygen levels to fall (warm water holds less oxygen than cool water). Photosynthesis decreases with lesser light, resulting in even lower oxygen levels. The occurrence of phytoplankton blooms in estuarine and coastal waters is also codetermined 
by the export of fluvial nutrients and other water properties such as turbidity. Phytoplankton community structures are affected by turbidity, here, cyanobacteria often dominate because of their ability to become buoyant.

The range of DO values in Jakarta Bay ranged from 4.53-8.43 $\mathrm{mg} / \mathrm{L}$ with Muara Baru had the highest DO average than other sampling points. In Muara Karang, the average DO was relatively low, which is likely due to its high turbidity. Oxygen is used by microorganisms to break down the particles in water column (Azam 1998; Liu et al. 2018). Temperature in Ancol was the highest, causing decreased oxygen content. As the temperature of the water increases, the solubility of oxygen decreases (Rahmawati and Surilayani 2017).

\section{Harmful algal abundance}

In this study, there were 5 genera of dinoflagellates recorded from twelve sampling points in Jakarta Bay, namely Ceratium, Dinophysis, Gonyaulax, Gymnodinium, and Noctiluca (Table 2). The abundance of dinoflagellate was significantly different $(\mathrm{P}<0.05, \mathrm{~F}=2.539)$ among genera (Figure 2). The genus of Noctiluca had the highest abundance with $85,279,547$ cells $/ \mathrm{m}^{3}$ followed by Ceratium $\left(7,360,226\right.$ cells $\left./ \mathrm{m}^{3}\right)$, while Dinophysis was the lowest with 353,857 cells $/ \mathrm{m}^{3}$. The order of abundance based on genera was Noctiluca $>$ Ceratium $>$ Gonyaulax $>$ Gymnodinium $>$ Dinophysis.

The genus of Noctiluca had the highest abundance across ten sampling points except in sampling points 1 and 3 (Ancol) (Table 2). The relative abundance of Noctiluca reaches more than $50 \%$ in those sampling points (Figure 3 ). The Ceratium showed similar distribution with Noctiluca which is absent in sampling points 1 and 3 (Table 2). The abundance of Ceratium genus was observed high in sampling points 5, 6 (Muara Baru), 8 (Muara Angke) and 12 (Muara Karang) with relative abundance in range of 16$33 \%$ (Figure 3). Gonyaulax was the only genus found in sampling point 1 (with relative abundance $100 \%$; Figure 3 ) and was also in high abundance in sampling point 3 (Table
2). Gymonodinium was absent in sampling points $1,5,7,9$ and 10. This genus has high relative abundance in sampling point 3. On the other hand, the genus of Dinophysis had only limited distribution and abundance across sampling sites which only found in sampling points 4, 6 (Muara Baru) and 11 (Muara Karang). The relative abundance of this genus was in range of $0.22-2.34 \%$ (Figure 3 ).

In regard to sampling location, the abundances were observed to be concentrated and high in Muara Baru with $50,176,929$ cells $/ \mathrm{m}^{3}$, followed by Muara Karang with 28,308,563 cells $/ \mathrm{m}^{3}$, while Ancol had the lowest abundance with $5,520,170$ cells $/ \mathrm{m}^{3}$ (Table 2). The order of dinoflagellate based on location sampling was Muara Baru > Muara Karang > Muara Angke > Ancol. Looking at more detail, the abundance of dinoflagellate was also different among sampling locations (Figure 4). Sampling point 4 located in Muara Baru had the highest abundance with $31,493,277$ cells $/ \mathrm{m}^{3}$, followed by sampling point 11 in Muara Karang with $15,640,481$ cells $/ \mathrm{m}^{3}$, while sampling point 3 in Ancol had the lowest with 141,543 cells $/ \mathrm{m}^{3}$ (Table 2).

Principal Component Analysis has separated sampling points $1,3,8$ since these sampling points have significant low dinoflagellate abundances (Figure 5). This supports finding in Figure 4 and Table 2, the abundance of those three stations is lower than another sampling (below one million cells $/ \mathrm{m}^{3}$ ).

Table 3 presented water variables that can promote and limit the dinoflagellate abundance based on Pearson correlation values. DO was positively correlated with the presence of all dinoflagellates. Whereas turbidity and $\mathrm{pH}$ had negative correlations with the presence of all dinoflagellates except turbidity versus Gymnodinium. Temperature was positively correlated with Ceratium, Gonyaulax, Gymnodinium and Dinophysis except for Noctiluca. Salinity had negative correlation with Ceratium, Dinophysis, Gymnodinium and positive correlation with Gonyaulax and Noctiluca.

Table 2. The abundance of dinoflagellate (cells $/ \mathrm{m}^{3}$ ) across genera and twelve sampling points in Jakarta Bay, Indonesia

\begin{tabular}{|c|c|c|c|c|c|c|c|}
\hline \multirow{2}{*}{\multicolumn{2}{|c|}{ Sampling points }} & \multicolumn{5}{|c|}{ Dinoflagellate abundance (cells/m³) } & \multirow{2}{*}{ Total } \\
\hline & & Ceratium & Dinophysis & Gonyaulax & Gymnodinium & Noctiluca & \\
\hline \multirow[t]{3}{*}{ Ancol } & 1 & - & - & 283,086 & - & - & 283,086 \\
\hline & 2 & 283,086 & - & 141,543 & 70,771 & $4,600,142$ & $5,095,541$ \\
\hline & 3 & - & - & 70,771 & 70,771 & - & 141,543 \\
\hline \multirow[t]{3}{*}{ Muara Baru } & 4 & $1,344,657$ & 70,771 & 495,400 & 141,543 & $29,440,906$ & $31,493,277$ \\
\hline & 5 & $1,627,742$ & - & - & - & $7,997,169$ & $9,624,912$ \\
\hline & 6 & $2,476,999$ & 212,314 & 283,086 & 141,543 & $5,944,798$ & $9,058,740$ \\
\hline \multirow[t]{3}{*}{ Muara Angke } & 7 & 212,314 & - & 70,771 & - & $1,273,885$ & $1,556,971$ \\
\hline & 8 & 70,771 & - & - & 70,771 & 70,771 & 212,314 \\
\hline & 9 & 70,771 & - & - & - & $9,412,597$ & $9,483,369$ \\
\hline \multirow[t]{3}{*}{ Muara Karang } & 10 & 141,543 & - & - & - & $9,907,997$ & $10,049,540$ \\
\hline & 11 & 495,400 & 70,771 & - & 141,543 & $14,932,767$ & $15,640,481$ \\
\hline & 12 & 636,943 & - & 141,543 & 141,543 & $1,698,514$ & $2,618,542$ \\
\hline Total & & $7,360,226$ & 353,857 & $1,486,200$ & 778,485 & $85,279,547$ & \\
\hline
\end{tabular}




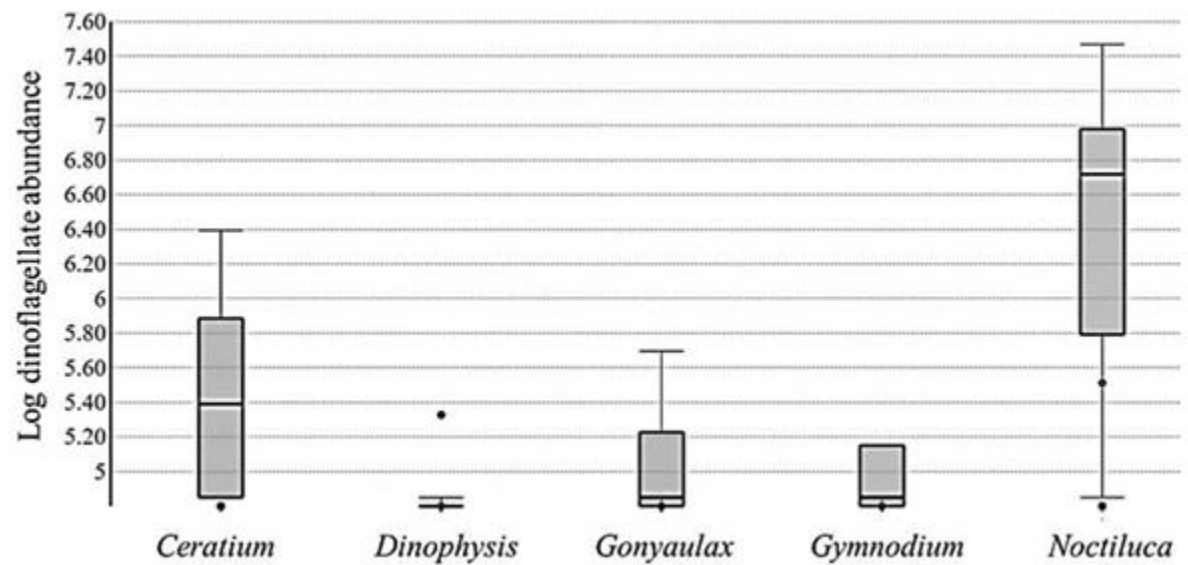

Figure 2. Box plots of log of the abundance of dinoflagellate $\left(\mathrm{cells} / \mathrm{m}^{3}\right)$ across genera in Jakarta Bay, Indonesia

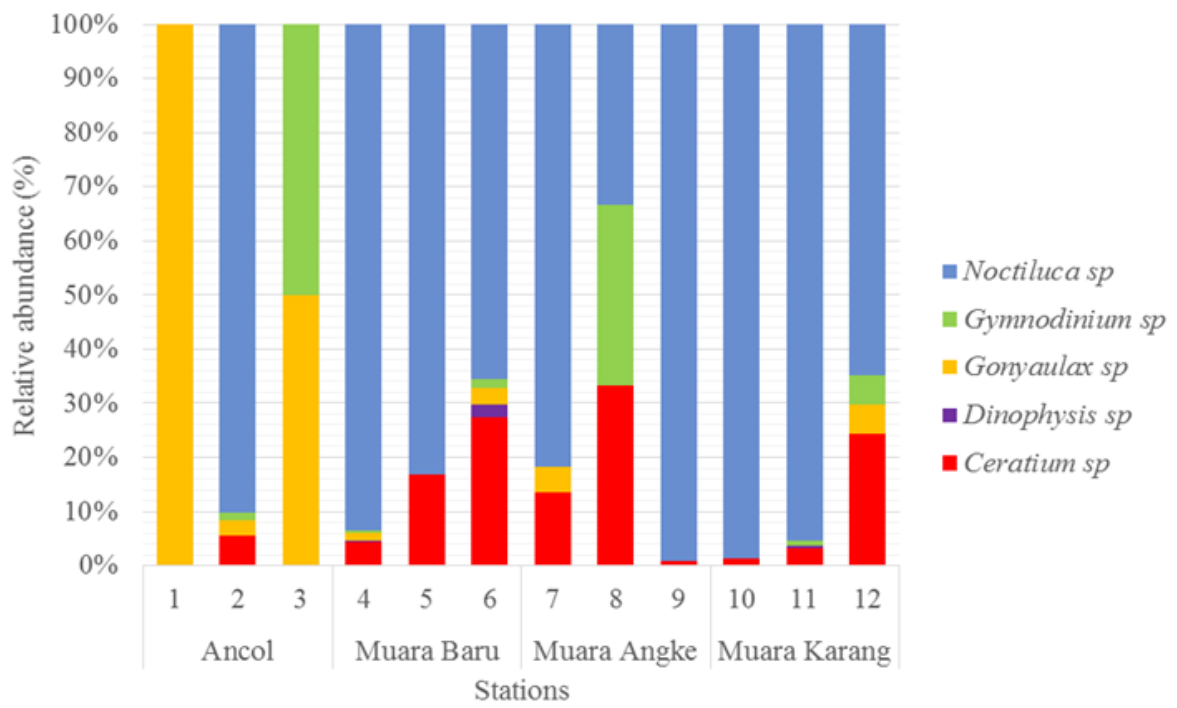

Figure 3. Relative abundance (\%) of dinoflagellates across genera and twelve sampling points in Jakarta Bay, Indonesia

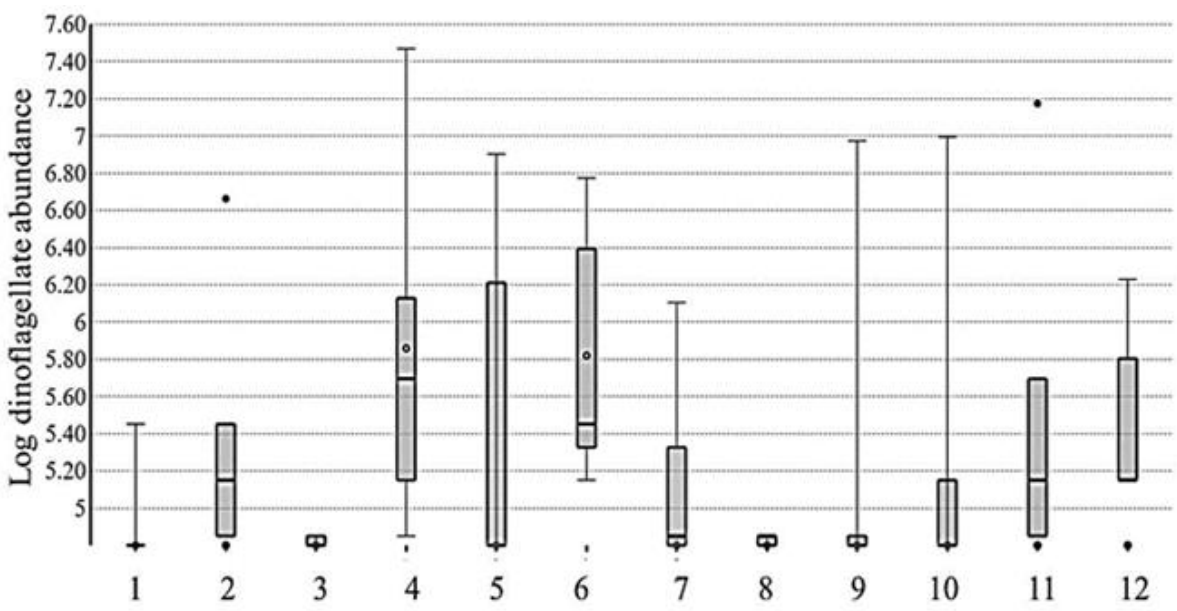

Figure 4. Box plots of log of the abundance of dinoflagellate $\left(\right.$ cells $\left./ \mathrm{m}^{3}\right)$ across 12 sampling points in Jakarta Bay, Indonesia 


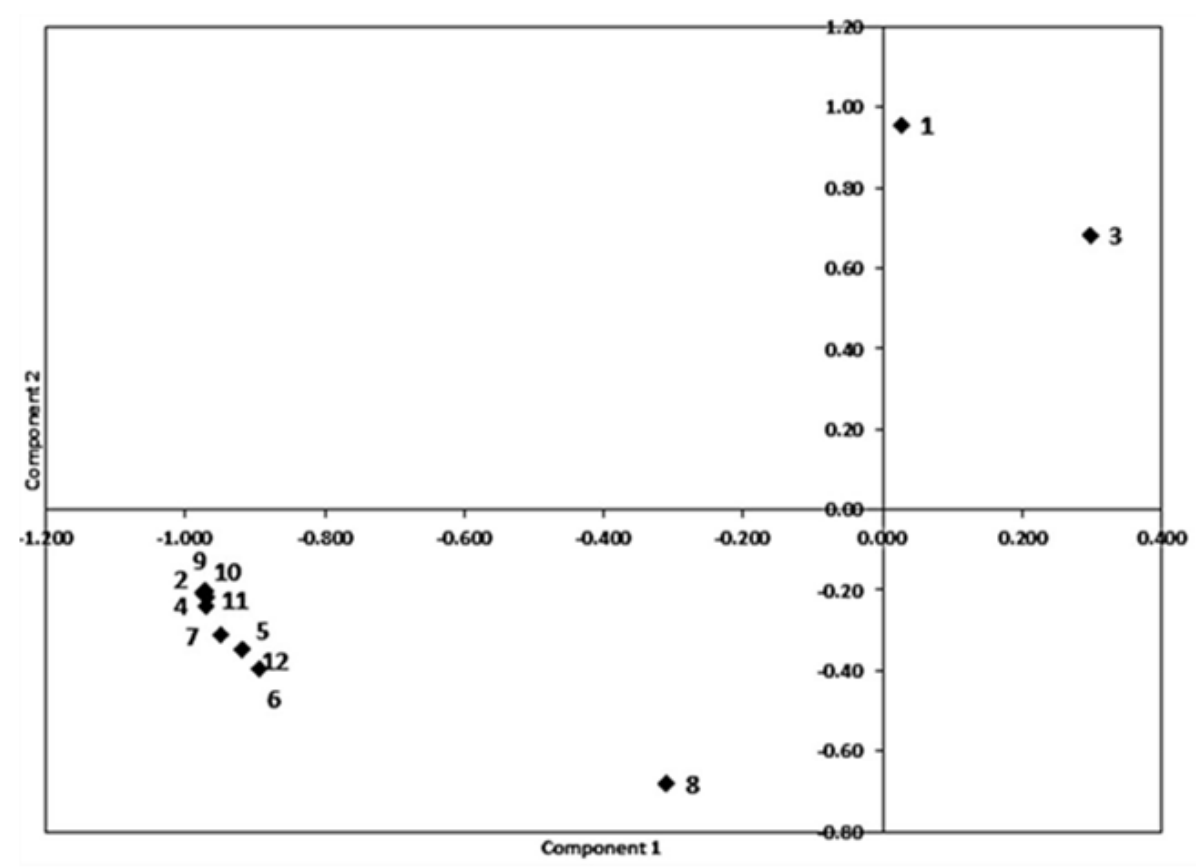

Figure 5. The results of Principal Component Analysis of twelve sampling points in Jakarta Bay, Indonesia

Table 3. Pearson's R correlation significance between harmful dinoflagellate abundance and water quality variables

\begin{tabular}{lccccc}
\hline & DO & pH & Temperature & Salinity & Turbidity \\
\hline Gymnodinium & 0.5152 & -0.4284 & 0.3894 & -0.2176 & 0.2713 \\
Dinophysis & 0.5262 & -0.4868 & 0.2536 & -0.0888 & -0.2336 \\
Gonyaulax & 0.3701 & -0.3881 & 0.3428 & 0.1080 & -0.0105 \\
Noctiluca & 0.0429 & -0.4201 & -0.0759 & 0.0729 & -0.1164 \\
Ceratium & 0.4168 & -0.5558 & 0.3627 & -0.0434 & -0.0896 \\
\hline
\end{tabular}

\section{Discussion}

Water quality parameters in Jakarta Bay obtained in this study were in agreement with another study (Nazula et al. 2019). In this bay, turbidity, temperature, salinity, and DO were water quality variables that have significant effects on the bay ecosystems. Ecologically, the temperature is an environmental factor that influences the presence of various aquatic organisms, including HABs. According to Bouman et al. (2003) and Ayadi et al. (2004), the temperature affects the changes in phytoplankton composition and size. DO values recorded here considered high which were within the range of $6-8 \mathrm{mg} / \mathrm{L}$ as reported by Martina and Radjawane (2019). This condition occurred because the research stations received freshwater inputs from the nearby rivers. The presence of rivers and freshwater will lead to the diffusion of oxygen in water and this will increase the DO.

Most apparent water quality can be observed in latitudinal turbidity data. Muara Baru and Muara Karang dominated by settlements that had higher turbidity, while Muara Angke and Ancol had lower values. Besides the presence of residential areas, turbidity values were also likely influenced by the presence of thirteen rivers at the head of Jakarta Bay. This similar condition was also reported by Yurista et al. (2015) in Green Bay (Lake of Michigan, Wisconsin). In their study, they observed river loading sets up the turbidity for a longitudinal along the Green Bay. Turbidity is related to the pollutants entering the bay most commonly via terrestrial run-off from rivers or through urban run-off carrying large amounts of residential wastes.

All dinoflagellates recorded in this study were categorized as harmful algal genera as reported by other studies (Smayda 1997; Aissaoui et al. 2012). Kunzmann et al. (2018) reported that water quality can affect marine organism patterns as happened in coral reefs where the reefs have varied patterns along with the water quality. Hard corals increase along with the degradation of water quality while soft corals have positive correlation in locations where water quality improved. In Jakarta Bay, dinoflagellate abundance had positive correlation with DO and negative correlation with turbidity. This finding corroborates the report by Sahu et al. (2014) which stated that low turbidity will favor the dinoflagellate abundance. A similar trend was also observed in Makassar Bay (Mujib et al. 2015). Turbidity is one of the important variables affecting the growth of dinoflagellate (Hilaluddin et al. 2020, Ge et al. 2020). High turbidity in inshore of Jakarta 
Bay will restrict the light penetration and this limits the dinoflagellate distribution in the water column.

In this study, the abundance of dinoflagellate was possibly related to human activities. Muara Baru and Muara Karang where the dinoflagellate abundances were notably high have coastal land uses dominated by settlements, industrial areas, and fish auction which include numerous factories and warehouses (Pratama and Tauchid 2018). Muara Angke is known for its 25.02 hectares of mangrove ecosystem and wildlife reserve in Jakarta (Cordova et al. 2021). Ancol has been one of the largest tourism complexes in Jakarta along with housing and industrial estates (Merrillees 2015). According to Gharib et al. (2011), coastal anthropogenic inputs can affect the distribution and composition of the phytoplankton assemblages. In coasts dominated by residential areas where anthropogenic nutrient inputs are more evident, phytoplankton abundance is strongly related to such nutrients.

Ceratium in Jakarta Bay was a dinoflagellate that occupied a large area especially in Muara Baru and Muara Karang. In these areas, Ceratium preferred more offshore than inshore areas. According to Mujib et al. (2015) with their study in Makassar Bay, Ceratium abundance was high in offshore and occupying a large area. The wide distributions of Ceratium that cover large areas were related to the adaption of this genus. Ceratium is known as dinoflagellate genus that has broad tolerance to the water quality including water with low salinity (Baek et al. 2008). In this study, Ceratium had negative correlation with salinity, meaning that its abundance was high when salinity was low. Noctiluca was dinoflagellate with the largest abundance, despite the fact that this genus has limited distribution. According to Mujib et al. (2015), Noctiluca has narrow tolerance to salinity and temperature. This narrow tolerance was supported by the findings by Tsai et al. (2018) that Noctiluca was correlated positively with salinity. As a result, Noctiluca abundance was high only in areas where salinity was high as well. Dinophysis and Gymnodinium were dinoflagellates that had low abundance and limited distribution. Dinophysis was distributed limited to the area that had low salinity. This preference for low saline water was similar to Mujib et al. (2015) results. Related to the morphology of Dinophysis, this genus has flagella to support its movement in the water. To enable the movement using flagella, Dinophysis requires appropriate water density and low saline water. Gymnodinium had positive correlation with turbidity and negative correlation with salinity. Most dinoflagellate requires low turbidity to grow, whereas considering its positive correlation with turbidity, Gymnodinium can inhabit complete dark water (Gómez 2003) with limited light penetration. According to Band-Schmidt et al. (2010), Gymnodinium has broad water quality tolerances. In Muara Angke, Gymnodinium was the only genus found there while other dinoflagellates were absent. In this location, the salinity was the lowest with 35 ppt while other dinoflagellates prefer salinity > 35 ppt. Gómez (2003) reported that Gymnodinium high abundance was associated with low salinity waters and this explains the only negative correlation of this genus with salinity in Jakarta Bay.

This study has reported the abundance of harmful dinoflagellate as function of water quality. It was apparent that DO and turbidity shaped the dinoflagellate presence in Jakarta Bay. Water with high DO and low turbidity was preferred by dinoflagellates except for Gymnodinium that can tolerate high turbidity. Jakarta Bay receives freshwater from several rivers. This condition reduces the salinity and also can favor the dinoflagellate distribution pattern mainly for those genera that can tolerate low saline water since they had negative correlations with salinity. Dinoflagellate genera that widely distributed in the bay with low salinity included Ceratium, Dinophysis and Gymnodinium.

\section{ACKNOWLEDGEMENTS}

The authors are grateful to the University of Indonesia for the funds provided through the Directorate of Research and Community Service (DRPM UI) under PUTI Saintekes 2020 funding scheme with contract number NKB4877/UN2.RST/HKP.05.00/2020.

\section{REFERENCES}

Aditya V, Koswara A, Fitriya N, Rachman A, Sidabutar T, Thoha H. 2013. Public awareness on harmful algal bloom (HAB) in Lampung bay. Mar Res Indones 38 (2): 71-75. DOI: 10.14203/mri.v38i2.58.

Aissaoui A, Turki S, Benhassine OK. 2012. Occurrence of harmful dinoflagellates in the Punic harbors of Carthage (gulf of Tunis, Tunisia) and their correlations with the physicochemical parameters. Bull Inst Nat Sci Technol Mer de Salammbô 39: 127-140.

Annisa R, Jiwandono K, Marteda G, Atmajaya GKM, Sinisuka NI, Dinata IS, Leilan F, Revina T, Iman D, Samuel D. 2019. Environmental impact assessment of electricity production from combined cycle steam power plants with life cycle assessment approach case study: Muara Karang Power Plant, 2nd International Conference on High Voltage Engineering and Power Systems (ICHVEPS), Denpasar, Indonesia. DOI: 10.1109/ICHVEPS47643.2019.9011095.

Ayadi H, Abid O, Elloumi J, Bouaïn A, Sime-Ngando T. 2004. Structure of the phytoplankton communities in two lagoons of different salinity in the Sfax Salters (Tunisia). J Plankton Res 26 (6): 669-679. DOI: 10.1093/plankt/fbh047.

Azam F. 1998. Microbial control of oceanic carbon flux: the plot thickens. Science 280 (5364): 694-696. DOI: 10.1126/science.280.5364.694

Baek SH, Shimode S, Han MY, Kikuchi T. 2008. Population development of the dinoflagellates Ceratium furca and Ceratium fusus during spring and early summer in Iwa Harbor, Sagami Bay, Japan. Ocean Sci J 43 (1): 49-59. DOI: 10.1007/BF03022431.

Band-Schmidt CJ, Bustillos-Guzmán JJ, López-Cortés DJ, GárateLizárraga I, Núñez-Vázquez EJ, Hernández-Sandoval FE. 2010. Ecological and physiological studies of Gymnodinium catenatum in the Mexican Pacific: A Review. Mar Drugs 8 (6): 1935-1961. DOI: 10.3390/md8061935.

Barokah GR, Putri AK, Gunawan. 2016. The abundance of phytoplankton causing HAB (Harmful Algal Bloom) in Lampung Bay during west and east monsoon. Jurnal Pascapanen dan Bioteknologi Kelautan dan Perikanan 11 (2): 115-126. DOI: 10.15578/jpbkp.v11i2.302. [Indonesian]

Barron S, Weber C, Marino R, Davidson E, Tomasky G, Howarth R. 2002. Effects of varying salinity on phytoplankton growth in a lowsalinity coastal pond under two nutrient conditions. Biol Bull 203 (2): 260-261. DOI: 10.2307/1543430.

Bouman HA, Platt T, Sathyendranath S, Li WKW, Stuart V, FuentesYaco C, Maass H, Horne EPW, Ulloa O, Lutz V, Kyewalyanga M. 2003. Temperature as an indicator of optical properties and community structure of marine phytoplankton: implications for 
remote sensing. Mar Ecol Prog Ser 258: 19-30. DOI: 10.3354/meps258019.

Boyd PW, Rynearson TA, Armstrong EA, Fu F, Hayashi K, Hu Z, Hutchins DA, Kudela RM, Litchman E, Mulholland MR, Passow U, Strzepek RF, Whittaker KA, Yu E, Thomas MK. 2013. Marine phytoplankton temperature versus growth responses from polar to tropical waters--outcome of a scientific community-wide study. PLoS One 8: e63091. DOI: 10.1371/journal.pone.0063091.

Clemenston LA, Parslow JS, Turnbull AR, Bonham PI. 2004. Properties of light absorption in a highly coloured estuarine system in south-east Australia which is prone to blooms of the toxic dinoflagellate Gymnodinium catenatum. Estuar Coast Shelf Sci 60 (1): 101-112. DOI: $10.1016 / j$.ecss.2003.11.022.

Cordova MR, Ulumuddin YI, Purbonegoro T, Shiomoto A. 2021. Characterization of microplastics in mangrove sediment of Muara Angke Wildlife Reserve, Indonesia. Mar Pollut Bull 163: 112012. DOI: 10.1016/j.marpolbul.2021.112012.

Corrales RA, Maclean JL. 1995. Impacts of harmful algae on seafaring in the Asia-Pacific areas. J Appl Phycol 7 (2): 151-162. DOI: 10.1007/BF00693062.

Cuellar-Martinez T, Ruiz-Fernández AC, Alonso-Hernández C, AmayaMonterrosa O, Diaz-Asencio L, Mendez SM, Vargas M, Chow-Wong NF, Valerio-Gonzalez LR, Enevoldsen H, Bottein MYD. 2018. Addressing the problem of harmful algal blooms in Latin America and the Caribbean-A regional network for early warning and response. Front Mar Sci 5: 409. DOI: 10.3389/fmars.2018.00409.

Davidson K, Gowen RJ, Harrison PJ, Fleming LE, Hoagland P, Moschonas G. 2014. Anthropogenic nutrients and harmful algae in coastal waters. J Environ Manag 146: 206-216. DOI: 10.1016/j.jenvm an.2014.07.002.

Díaz PA, Ruiz-Villarreal M, Pazos Y, Moita T, Regeura B. 2016. Climate variability and Dinophysis acuta blooms in an upwelling system. Harmful Algae 53: 145-159. DOI: 10.1016/j.hal.2015.11.007.

Fawcett A, Bernard S, Pitcher G, Probyn TA, Randt A. 2006. Real-time monitoring of harmful algal blooms in the southern Benguela. Afr J Mar Sci 28 (2): 257-260. DOI: 10.2989/18142320609504158.

Furuya K, Iwataki M. Lim PT, Lu S, Leaw CP, Azanza R, Kim HG, Fukuyo Y. 2018. Overview of harmful algal blooms in Asia. In: Gilbert PM, Berdalet E, Burford MA, Pitcher GC, Zhou M. (eds) Global Ecology and Oceanography of Harmful Algal Blooms. Springer. DOI: 10.1007/978-3-319-70069-4_14

Ge J, Torres R, Chen C, Liu J, Xu Y, Bellerby R, Shen F, Bruggeman J, Ding P. 2020. Influence of suspended sediment front on nutrients and phytoplankton dynamics off the Changjiang Estuary: A FVCOMERSEM coupled model experiment. J Mar Syst 204: 103292. DOI: 10.1016/j.jmarsys.2019.103292

Gharib SM, El-Sherif ZM, Abdel-Halim AM, Radwan AA. 2011. Phytoplankton and environmental variables as a water quality indicator for the beaches at Matrouh, south-eastern Mediterranean Sea, Egypt. Oceanologia 53 (3): 819-836. DOI: 10.5697/oc.53-3.819.

Gómez F. 2003. The toxic dinoflagellate Gymnodinium catenatum: an invader in the Mediterranean Sea. Acta Bot Croat 62 (2): 65-72.

Guiry MD. 2012. How many species of algae are there? J Phycol 48 (5): 1057-1063. DOI: 10.1111/j.1529-8817.2012.01222.x.

Hagens M, Middelburg JJ. 2016. Attributing seasonal pH variability in surface ocean waters to governing factors. Geophys Res Lett 43 (24): 1258-12537. DOI: $10.1002 / 2016$ GL071719.

Hilaluddin F, Yusoff FMd, Toda T. 2020. Shifts in diatom dominance associated with seasonal changes in an estuarine-mangrove phytoplankton community. J Mar Sci Eng 8 (7): 528. DOI $10.3390 /$ jmse 8070528

Hinga KR. 2002. Effects of pH on coastal marine phytoplankton. Mar Ecol Prog Ser 238: 281-300. DOI: 10.3354/meps238281.

Horiguchi T. 2015. Diversity and phylogeny of marine parasitic dinoflagellates. In: Ohtsuka S, Suzaki T, Horiguchi T, Suzuki N, Not F, (eds) Marine Protists. Springer, Tokyo.

Kunzmann A, Arifin Z, Baum G. 2018. Pollution of coastal areas of Jakarta bay: Water quality and biological responses. Mar Res Indones 43 (1): 37-51. DOI: $10.14203 /$ mri.v43i1.299.

Lassus P, Chomérat N, Hess P, Nézan E. 2016. Toxic and Harmful Microalgae of the World Ocean-Microalgues Toxiques et Nuisibles de l'océan Mondial. IOC Manuals and Guides, Copenhagen.

Le Bescot N, Mahé F, Audic S, Dimier C, Garet MJ, Poulain J, Wincker P, de Vargas C, Siano R. 2016. Global patterns of pelagic dinoflagellate diversity across protist size classes unveiled by metabarcoding. Environ Microbiol 18 (2): 609-626. DOI: 10.1111/1462-2920.13039.

León-Muñoz J, Urbina MA, Garreaud R, Iriarte JL. 2018. Hydroclimatic conditions trigger record harmful algal bloom in western Patagonia (summer 2016). Sci Rep 8 (1): 1-10. DOI: 10.1038/s41598-01819461-4.

Liu Q, Fang J, Li J, Zhang L, Xie BB, Chen XL, Zhang YZ. 2018. Depthresolved variations of cultivable bacteria and their extracellular enzymes in the water column of the New Britain Trench. Front Microbiol 9: 135. DOI: 10.3389/fmicb.2018.00135.

Lu S, Hodgkiss I. 2004. Harmful algal bloom causative collected from Hong Kong waters. Hydrobiologia 512: 231-238. DOI: 10.1023/B:HYDR.0000020331.75003.18

Martina A, Radjawane IM. 2019. Data analysis on seawater quality data in Jakarta Bay using Principal Components Analysis (PCA) method during transitional monsoon. IOP Conf Ser: Earth Environ Sci 339 (1): 012023. DOI: 10.1088/1755-1315/339/1/012023.

Matsuoka K, Fukuyo Y, Praseno DP, Adnan Q, Kodama M. 1999. Dinoflagellate cysts in surface sediments of Jakarta Bay, off Ujung Pandang and Larantuka of Flores Islands, Indonesia with special reference of Pyrodinium bahamense. Bulletin of Faculty Fisheries, Nagasaki University 80: 49-54.

Merrillees S. 2015. Jakarta: Portraits of a Capital 1950-1980. Equinox Publishing, Jakarta.

Mujib AS, Damar A, Wardiatno Y. 2015. Spatial distribution of planktonic dinoflagellate in Makassar waters, South Sulawesi. Jurnal Ilmu dan Teknologi Kelautan Tropis 7 (2): 479-492. DOI: 10.29244/jitkt.v7i2.11033. [Indonesian]

Nagai S, Chen H, Kawakami Y, Yamamoto K, Sildever S, Kanno N, Oikawa $H$, Yasuike $M$, Nakamura $Y$, Hongo $Y$, Fujiwara A, Kobayashi T, Gojobori T. 2019. Monitoring of the toxic dinoflagellate Alexandrium catenella in Osaka Bay, Japan using a massively parallel sequencing (MPS)-based technique. Harmful Algae 89: 101660. DOI: 10.1016/j.hal.2019.101660.

Nazula AH, Rahman A, Winarso G. 2019. Metode pemetaan sebaran klorofil-a secara spasial dan temporal di Teluk Jakarta menggunakan citra Aqua MODIS. In: Anggraini N, Mukhoriyah, Febrianti N, Rahayu MI, Gumelar O, Gustandi B, Lestari AI, Monica D (eds) Peningkatan Pemanfaatan IPTEK Penginderaan Jauh untuk Mendukung Pencapaian Tujuan Pembangunan Berkelanjutan (SDGs); Prosiding Seminar Nasional Penginderaan Jauh 2019. Margo Hotel, Depok, 17 July 2019. [Indonesian]

Omura T, Iwataki M, Borja V M, Takayama H, Fukuyo Y. 2012. Marine Phytoplankton of the Western Pacific. Kouseisha Kouseikaku Co Ltd, Tokyo.

Prabowo DA, Agusti S. 2019. Free-living dinoflagellates of the central Red Sea, Saudi Arabia: Variability, new records and potentially harmful species. Mar Pollut Bull 141: 629-648. DOI: 10.1016/j.marpolbul.2019.03.012.

Praseno DP, Sugestiningsih. 2000. Retaid di Perairan Indonesia. Pusat Penelitian dan Pengembangan Oseanologi-LIPI, Jakarta. [Indonesian]

Pratama NI, Noor AT. 2018. Kampung Muara Baru dan identitas. https://rujak.org/kampung-muara-baru-dan-identitas. [Indonesian]

Probyn TA, Pitcher GC, Monteiro PMS, Boyd AJ, Nelson G. 2000. Physical processes contributing to harmful algal blooms in Saldanha Bay, South Africa. South Afr J Mar Sci 22 (1): 285-297. DOI: 10.2989/025776100784125807

Rahmawati A, Surilayani D. 2017. Pengelolaan kualitas perairan pesisir desa Lontar, Banten. Jurnal Perikanan dan Kelautan 7: 59-70. DOI: 10.33512/jpk.v7i1.1951. [Indonesian]

Raymont JEG. 1980. Plankton and Productivity in the Ocean. Mc. Millan Co., New York

Riqqi A, Fawaid A, Driejana. 2019. Perancangan potensi lokasi jejaring stasiun pemantau kualitas udara di daerah urban berbasis data spasial studi kasus di DKI Jakarta. Majalah Globe 21 (1): 27-34. DOI: 10.24895/MIG.2019.21-1.876. [Indonesian]

Sahu G, Mohanty AK, Samantara MK, Satpathy KK. 2014. Seasonality in the distribution of dinoflagellates with special reference to harmful algal species in tropical coastal environment, Bay of Bengal. Environ Monit Assess 186 (10): 6627-6644. DOI: 10.1007/s10661-014-38783.

Sew G, Todd P. 2020. Effects of salinity and suspended solids on tropical phytoplankton mesocosm communities. Trop Conserv Sci 13: 1-11. DOI: $10.1177 / 1940082920939760$.

Sidabutar T, Bengen DG, Wouthuyzen S, Partono T. 2016. The abundance of phytoplankton and its relationship to the N/P ratio in Jakarta Bay, 
Indonesia. Biodiversitas $17 \quad$ (2): 673-678. DOI: 10.13057/biodiv/d170241.

Sidabutar T, Srimariana ES, Wouthuyzen S. 2020. The potential role of eutrophication, tidal and climatic on the rise of algal bloom phenomenon in Jakarta Bay. IOP Conf Ser: Earth Environ Sci 429 (1): 012021. DOI: 10.1088/1755-1315/429/1/012021.

Sidharta BR. 2004. Fish mass mortality in Jakarta Bay: HAB organisms as the culprit? Harmful Algal News 27: 8-9.

Smayda TJ. 1997. Harmful algal blooms: their ecophysiology and general relevance to phytoplankton blooms in the sea. Limnol Oceanogr 42 : 1137-1153. https://doi.org/10.4319/lo.1997.42.5_part_2.1137.

Smayda TJ. 2007. Reflections on the ballast water dispersal-harmful algal bloom paradigm. Harmful Algae 6 (4): 601-622. DOI: 10.1016/j.hal.2007.02.003.

Soon EY, Sulit VT. 2017. Monitoring and identification of harmful algal blooms in Southeast Asia to support SDG 14.1. Fish for the People 15 (1): $39-46$.

Thoha H, Adnan Q, Sidabutar T, Sugestiningsih. 2007. Note on the occurrence of phytoplankton and its relation with mass mortality in the Jakarta Bay, May and November 2004. Makara J Sci 11: 63-67. DOI: $10.3389 /$ fmicb.2019.00306
Thoha H, Muawanah, Bayu Intan MD, Rachman A, Sianturi OR, Sidabutar T, Iwataki M, Takahashi K, Avarre JC, Masseret E. 2019. Resting cyst distribution and molecular identification of the harmful dinoflagellate Margalefidinium polykrikoides (Gymnodiniales, Dinophyceae) in Lampung Bay, Sumatra, Indonesia. Front Microbiol 10: 306. DOI: 10.3389/fmicb.2019.00306.

Tsai SF, Wu LY, Chou WC, Chiang KP. 2018. The dynamics of a dominant dinoflagellate, Noctiluca scintillans, in the subtropical coastal waters of the Matsu archipelago. Mar Pollut Bull 127: 553558. DOI: 10.1016/j.marpolbul.2017.12.041.

Wang DZ. 2008. Neurotoxins from marine dinoflagellates: a brief review. Mar Drugs 6 (2): 349-371. DOI: 10.3390/md6020349.

Wiadnyana NN, Sidabutar T, Matsuoka K, Ochi T, Kodama M, Fukuyo Y. 1996. Note on the occurrence of Pyrodinium bahamense in eastern Indonesian waters. In: Yasumoto T, Oshima Y, Fukuyo Y (eds) Harmful and Toxic Algal Blooms. International Oceanographic Commission of UNESCO.

Yamaji I. 1966. Illustrations of The Freshwater Plankton of Japan. Hokusha Publishing, Japan.

Yurista PM, Kelly JR, Anne MC, Miller SE, Van Alstine JD. 2015. Green Bay: Spatial variation in water quality, and landscape correlations. J Great Lakes Res 41 (2): 560-572. DOI: 10.1016/j.jglr.2015.03.014. 